\title{
DORSOPATHIES: ROUTINE CHECKUPS AS A PROCEDURE NECESSARY FOR EARLY DIAGNOSTICS, RISK FACTORS AND COMORBIDITIES IDENTIFICATION
}

\author{
Denisov $\mathbb{I N}^{1}$, Zaugolnikova TV¹, Popova TS ${ }^{1,2} \otimes$, Morozova TE ${ }^{1}$ \\ Department of General practice, \\ Sechenov First Moscow State Medical University (Sechenov University), Moscow \\ ${ }^{2}$ First Doctor clinic, Moscow
}

\begin{abstract}
Early detection of dorsopathies is an urgent task for primary care physicians, since such conditions can combine with other chronic noncommunicable diseases (NCD) and adversely affect the course all comorbidities, consequently disimproving the quality of life of patients and increasing the frequency of their requests for medical assistance. This study aimed to determine the value of routine checkups in the context of detection of dorsopathies, NCD, and identification of risk factors (RF). We have retrospectively analyzed the patient records database of a rural outpatient clinic in the Tver region (years 2015 to 2017). The prevalence of dorsopathies and NCD RF were the subjects investigated. Fisher's exact test and Spearman's rank correlation coefficient (SRCC) were applied for the purposes of statistical processing of the results. We discovered that dorsopathy most often was a comorbidity to arterial hypertension and gastrointestinal tract diseases; it was strongly related to the NCD (SRCC = 0.506), age (SRCC $=0.383$ ), slightly less so - to hypodynamia ( $S R C C=0.146)$, type of the patient's occupation (intellectual or physical labor) ( $\mathrm{SRCC}=0.07$ ). Routine checkups improve the rate of detection of dorsopathy: the more patients undergo such examinations, the more cases of dorsopathy are diagnosed. Thus, it is necessary to increase the number of working people attending the checkups in order to detect dorsopathies early and prevent them effectively.
\end{abstract}

Keywords: preventive medical examination, dorsopathy, risk factors, comorbidity, village resident.

Acknowledgment: authors of the study express their gratitude to L.V. Tyazhelova, head physician of the Mokshino outpatient clinic (Konakovo district, Tver region) for assistance in collecting material for the article and providing a room to work with the papers

$\triangle$ Correspondence should be addressed: Tatyana S. Popova Severny Boulevard, 7B, Moscow, 127566; bluesfinks@mail.ru

Received: 06.09.18 Accepted: 05.11.18

DOI: 10.24075/brsmu.2018.065

\section{ДОРСОПАТИИ: АКТУАЛЬНОСТЬ ПРОФИЛАКТИЧЕСКИХ ОСМОТРОВ ДЛЯ РАННЕЙ ДИАГНОСТИКИ, ВЫЯВЛЕНИЯ ФАКТОРОВ РИСКА И КОМОРБИДНЫХ ЗАБОЛЕВАНИЙ}

\author{
И. Н. Денисов ${ }^{1}$, Т. В. Заугольникова ${ }^{1}$, Т. С. Попова ${ }^{1,2}{ }^{凶}$, Т. Е. Морозова \\ ${ }^{1}$ Кафедра общей врачебной практики, \\ Первый Московский государственный медицинский университет имени И. М. Сеченова (Сеченовский университет), Москва \\ 2 ООО Клиника «Первый доктор», Москва
}

\begin{abstract}
Лечебно-профилактические мероприятия по ранней диагностике дорсопатий являются актуальной задачей врачей первичного звена здравоохранения. Это обусловлено тем, что сочетание дорсопатий с другими хроническими неинфекционными заболеваниями (ХНИЗ) формирует коморбидность, которая неблагоприятно влияет на их течение и исходы, увеличивает обращаемость населения за медицинской помощью, ухудшает качество жизни пациентов. Целью работы было определить значение профилактических осмотров в диагностике дорсопатий, сопутствующих ХНИЗ, и выявлении факторов риска (ФР). Проведен ретроспективный анализ базы данных амбулаторных карт пациентов сельской амбулатории Тверской области за 2015-2017 гг. Исследовали распространенность дорсопатий и ФР ХНИЗ. При статистической обработке применяли точный критерий Фишера и коэффициент ранговой корреляции Спирмена (KPKC). Было показано, что дорсопатия чаще всего сочеталась с артериальной гипертензией и заболеваниями желудочно-кишечного тракта, имеет сильную корреляционную связь с сопутствующими ХНИЗ (KPКС = 0,506); возрастом (KPKC = 0,383); более слабую с гиподинамией (KPKC = 0,146) и слабую с видом деятельности пациента (интеллектуальным или физическим трудом) (КPKC = 0,07). Профилактические осмотры улучшают диагностику дорсопатии - число выявляемых случаев заболевания растет с увеличением количества обследуемых в рамках профилактических осмотров пациентов. Таким образом, необходимо шире проводить профилактические осмотры для работающего населения с целью раннего выявления дорсопатии и эффективной ее профилактики.
\end{abstract}

Ключевые слова: профилактические осмотры, дорсопатия, фракторы риска, коморбидность, жители села

Благодарности: главному врачу Мокшинской амбулатории Конаковского района Тверской области Л. В. Тяжеловой за содействие при сборе материала для статьи и предоставление помещения для работы с документацией.

рореспонденции: Татьяна Сергеевна Попова

Северный бульвар, д. 7Б, г. Москва, 127566; bluesfinks@mail.ru

Статья получена: 06.09.18 Статья принята к печати: 05.11.18

DOI: $10.24075 /$ vrgmu.2018.065 
World Health Organization (WHO) announced prevention and treatment of noncommunicable chronic diseases (NCD) a priority project of the second decade of the 21st century, one aimed at improving the quality of life of the world's population [1]. There are two directions to the project: 1) healthy lifestyle education and promotion and 2) early detection of NCDs, learning the relevant risk factors (RF) and their timely correction. It is the healthcare systems of the countries that ensure progress in the second direction, with primary care physicians - district doctors, general practitioners (family doctors) playing a special role: $30-40 \%$ of their working time should be dedicated to activities aimed at prevention [2].

Diseases of the musculoskeletal system and connective tissue (DMSCT) are common; there are over 150 different conditions and syndromes belonging to the group, most of which usually cause pain and musculoskeletal system dysfunction. In the developed countries, the average age of people living in densely populated areas increases, which makes DMSCTs a frequently registered trigger of disability. In 2000, WHO launched The Bone and Joint Decade 20002010 , the goal of which was to increase the awareness of the existing problem throughout the world. Some of the initiatives undertaken within the decade implied studying medical, social and economic load born by the society in connection with the musculoskeletal system disorders, comprehensive understanding of RF affecting development and progression of musculoskeletal pathologies, as well as comorbidities [3]. According to the data published in 2016, every third European citizen complaining of pain in muscles, bones and joints, has limited ability to move the limbs, with the share of people affected ranging from $18 \%$ in Ireland to $46 \%$ in Croatia [4]. Lower back pain is the most common complaint $111 \%$ of all patients). People 55 years of age and older suffer pain twice as often. Women have the condition more often than men: $37 \%$ and $27 \%$, respectively [4].

Demographic changes (population ageing) and lifestylerelated RFs of NCDs allow forecasting the further spread of the pathologies belonging to this group. DMSCT are often accompanied by the cardiovascular diseases. Such comorbidities are always a complicated case, which is one of the reasons of the increased mortality rate among patients suffering them $[5,6]$.

This study aimed to determine the value of routine checkups in the context of early detection of dorsopathies, NCDs and their risk factors (RF).

\section{METHODS}

The subject of this research were reports made at Mokshino rural outpatient clinic and covering two districts (general practitioners) of Konakovo district of the Tver region. Namely, we studied the main indicators for 2011-2016: annual reports (forms 30, 12), "Outpatient medical history records" (UF \#025/u); "Routine checkup control records" (UF \#030/u);
"Additional checkup registration records (working citizen)" (UF \#131/u-DD-10) and other record forms related to preventive and additional medical examinations of working population. We have retrospectively analyzed the 2015-2017 patient records database. 1203 records containing a dorsopathy diagnosis were selected for the purposes of analysis of age-related specifics of comorbidities' development. Inclusion criteria: men and women aged 18 years and older, diagnosed with dorsopathy, signed the informed consent.

Exclusion criteria: age below 18, no dorsopathy in the anamnesis. Time of first complaints, dorsopathy diagnosis date, presence of RF and comorbidities peculiar to these patients were analyzed.

The study protocol \#10-16 of 11/09/2016 was approved by the local ethics committee of Sechenov University. Dividing the patients into groups and categories, we used the classification developed by WHO: young (18-44 years), middle-aged (44-60 years), senior (60-75 years), old-aged (75-90 years), long-livers (90+ years).

Diagnostic criteria recommended by Appendix \#2 to the Order \#1006n of 03.12.2012 issued by the Ministry of Health of Russia were referred to when determining the RF and pathological conditions and diseases.

\section{Statistical processing}

Planning the study, we determined the size of the sample to be taken from the Mokshino outpatient clinic's database with the help of the Sample Size modules of COMPARE 23.85 and DESCRIBE 3.18 programs of WinPEPI ${ }^{\circ} 11.65$ software package (author and copyright holder - J. H. Abramson). Fisher's exact test was applied in the context of statistical processing of the results. Investigating the relations between dorsopathy, RF, other NCDs, we used SRCC. The statistical significance threshold was set at $5 \%$.

\section{RESULTS}

The number of patients diagnosed with dorsopathies grows proportionally to the number of those undergoing routine checkups, even with the number of visits to the outpatient clinic and the number of patients registered at the clinic decreasing (by 2.6\% (159 people) and 1.6\% (35 people), respectively) (see Table, Fig. 1 and 2).

Figure 3 shows the presence of NCDs RFs in lives of 1203 rural residents (540 men and 663 women). The most common RFs for men were smoking (73\%) and hypercholesterolemia (17.3\%). The predominant RF for women was excess body weight (39.8\%).

Arterial hypertension $(\mathrm{AH})$ was the most widely-spread condition: 516 patients (42.9\% of all examined, $42,892.76$ cases per 100,000 people) suffered from it, including 207 men (38.3\% of all men examined) and 309 women (46.6\% of all women examined). The gender differences are statistically significant

Table. Routine checkups and detected cases of dorsopathy in numerical terms, adults, Mokshino outpatient clinic, $2011-2016$

\begin{tabular}{|c|c|c|c|c|c|c|}
\hline \multirow{2}{*}{ Indicators } & \multicolumn{6}{|c|}{ Reporting period, year } \\
\hline & 2011 & 2012 & 2013 & 2014 & 2015 & 2016 \\
\hline Number of people registered & 2237 & 2216 & 2217 & 2206 & 2217 & 2202 \\
\hline Number of visits to the clinic & 6122 & 6640 & 5587 & 5963 & 6784 & 5963 \\
\hline Number of routine checkups & 1033 & 1128 & 1033 & 1493 & 1776 & 1493 \\
\hline Diagnosed dorsopathies (\# of people) & 257 & 253 & 281 & 299 & 327 & 347 \\
\hline $\begin{array}{l}\text { Number of dorsopathy patients in follow-up care } \\
\text { at the end of the reporting year }\end{array}$ & 257 & 263 & 280 & 299 & 324 & 345 \\
\hline
\end{tabular}


$(p=0.004)$. From the point of view of prevalence, dorsopathy was next to arterial hypertension: it was detected in 347 patients (28.8\% of all examined ), which translates into $28,844.56$ cases per 100,000 people; they were 147 men $(27.2 \%$ of all men examined) and 200 women (30.2\% of all women examined). Here, gender differences were not statistically significant $(p=0.004)$. Gastrointestinal tract diseases (except for gastric ulcer and duodenal ulcer) followed dorsopathies: such were detected in 141 patients (11.7\% of all examined, 11,720.69 cases per 100,000 people), including 44 men (8.1\% of all men examined) and 97 women (14.6\% of all women examined). The gender differences are statistically significant ( $p=0.004$; Fig. 4). In 2016, dorsopathy was diagnosed in 82 young people (18-44 years old), which is $23.9 \%$ of all dorsopathy patients; in the middle-aged group (44-60 years), there were 127 cases (36.6\%), and in the senior (60-75 years) and further groups dorsopathy diagnosis was announced to 137 (39.5\%) persons.

In different years from 2011 to $2016,99.1$ to $100 \%$ of dorsopathy patients were observed by the Mokshino outpatient clinic's general practitioner (see Table).

In $31.7 \%$ of patients, dorsopathy was the only disease; in $28.5 \%$, it combined with one other disorder, in 40\% dorsopathy had two comorbidities (percentages of the total number of dorsopathy patients).

Two most frequent comorbidities were arterial hypertension (191 cases, $55.0 \%$ of all dorsopathy patients) and gastrointestinal tract diseases except for gastric ulcer and duodenal ulcer (67 cases, 19.3\% of all dorsopathy patients). Less common diseases diagnosed together with dorsopathy were coronary heart disease (33 cases, 9.5\% of all dorsopathy patients), obesity (27 cases, $7.8 \%$ of all dorsopathy patients), diabetes mellitus (20 cases, $5.8 \%$ of all dorsopathy patients), gastric ulcer and duodenal ulcer (17 cases, $4.9 \%$ of all dorsopathy patients), chronic diseases of the respiratory system (15 cases, $4.3 \%$ of all dorsopathy patients). Women suffer the aforementioned comorbidities (except for the coronary heart disease) more often than men. Significantly more women had diabetes mellitus and obesity as comorbidities of dorsopathy than men: $8.0 \%$ against $2.7 \%$ with diabetes, $12.5 \%$ against $1.4 \%$ with obesity, respectively. Coronary heart disease was detected in patients with dorsopathy in equal proportions gender-wise (9.5\%).

SRCC values for dorsopathy and NCDs' RF peculiar to the population group of rural residents studied are shown on Fig. 2 (2016). NCDs and age (SRCC values of 0.506 and 0.383 , respectively) correlate with dorsopathy more often than any other factor. Hypodynamia's correlation is weaker (SRCC = 0.146 ), that of the type of the patient's occupation (intellectual or physical labor) - even less so (SRCC $=0.07$ ). As for the inverse correlation ties, the strongest was with simple absence of any comorbidity (SRCC $=-0.406$ ), a weaker one - with alcohol abuse (SRCC $=-0.006)$. In the studied sample of dorsopathy patients (347 people), gender differences were not statistically significant $(p=0.004)$.

\section{DISCUSSION}

In 2016, DMSCTs (as described by ICD 10: M00-M99, dorsopathy included) incidence in Russia was 2,953.2 cases per 100,000 people nationwide and 9,402.5 cases per 100,000

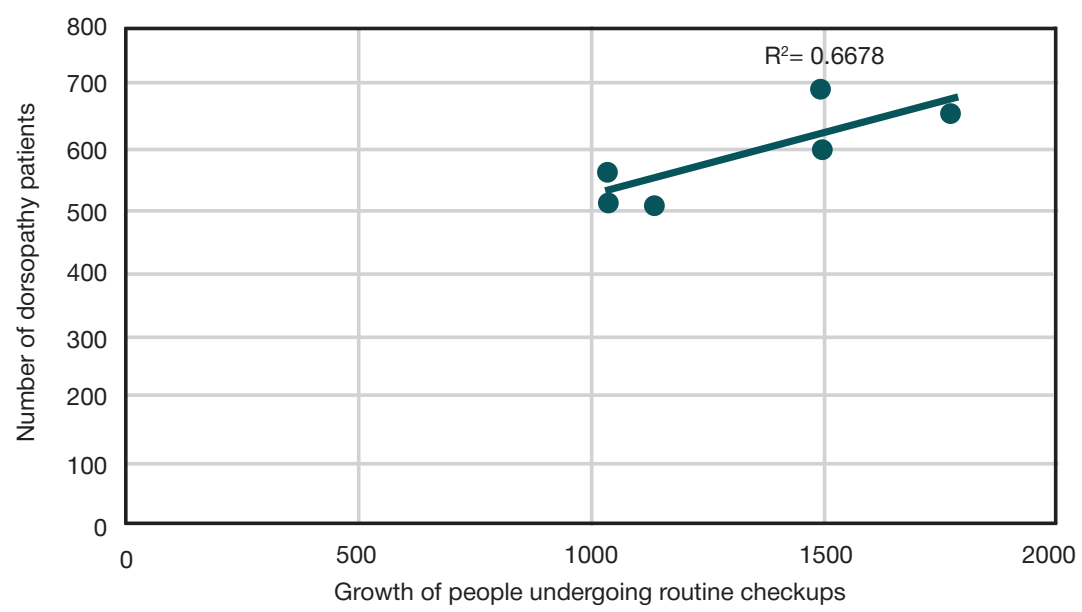

Fig. 1. Growth of the number of dorsopathy patients concurrent with the growth of people undergoing routine checkups, 2011-2016

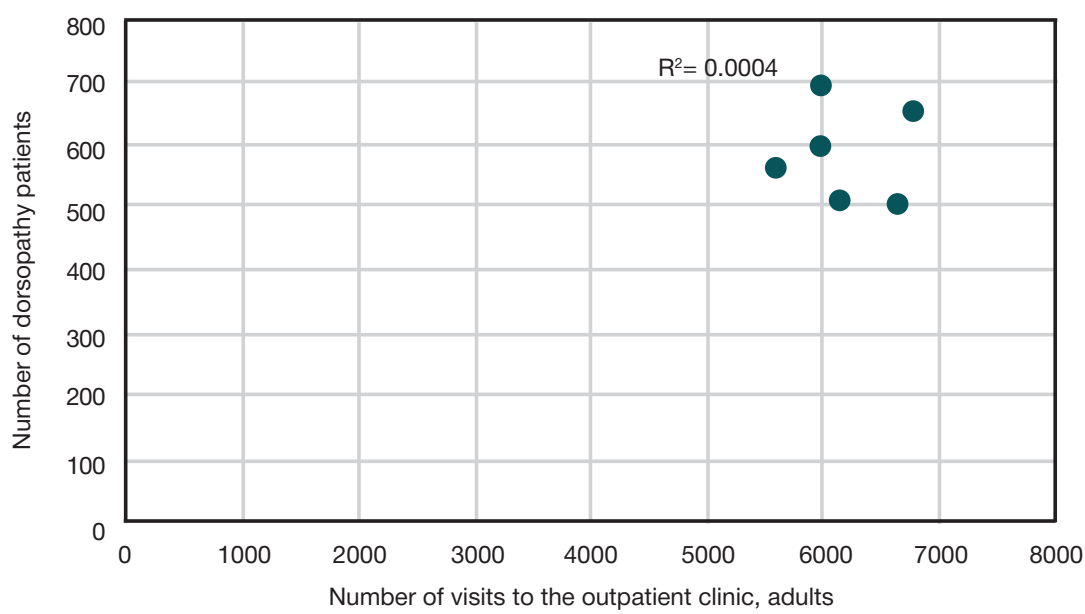

Fig. 2. Dot diagram reflecting distribution of the number of dorsopathy patients and number of visits to the Mokshino outpatient clinic (adults, 2011-2016) 
rural residents. In the Central Federal District, the figure was $8,707.4$ cases per 100,000 rural residents. In the Tver region in 2016 - 11,179.5 cases per 100,000 rural residents [7]. Thus, dorsopathy incidence as registered by the Mokshino outpatient clinic in 2016, which is $28,844.56$ cases per 100,000 people, is 3.1 times higher than the statistically average incidence of DMSCTs detected in residents of the rural areas of Russia; as for the Central Federal District's rural population, the Mokshino figure is 3.3 times greater. The number of rural residents beyond employable age has grown by $2.5 \%$ in the period between 2004 and 2013 in Russia, and continues to grow [8]. Tver region is one of the national leaders by the number of such residents living there (in \%); in the Central Federal District, it ranks 2nd (as of January 1, 2016) with $32.4 \%$ people living outside of cities being beyond working age [9]. Population ageing can be the explanation of high incidence of dorsopathy in the studied population group: out data indicates that age and dorsopathy have the strongest intercorrelation (SRCC = 0.383; Fig. 4).

Dorsopathy incidence as registered by the Mokshino outpatient clinic in 2016, which is $28,844.56$ cases per 100,000 people, is 2.6 times higher than Tver region average as reported by Rosstat (DMSCTs, rural population). [7]. Such figures call for further research of the disease and identification of the causes of its spread in this population.

At the international level, there is no single generally accepted dorsopathy definition and assessment routine. Most often, it is looked for in the context of examinations following complaints of chronic pain in the musculoskeletal system (pain persistent for at least three months of the past 12 months). The largest replicated cross-sectional studies with identical questions aimed at researching the prevalence of chronic pain in musculoskeletal system are the studies conducted in 19951997 ( $n=92,936)$ and 2006-2008 ( $n=94,194)$ in Norway, which enlisted adults aged 20 and over; these studies revealed that through the 11 years, the incidence of such diseases has grown significantly, with senior women (50 y.o. and older), smoking and overweight people facing a particular risk. Disorders of musculoskeletal system were spreading especially quickly among people 20-29 y.o. during those 11 years. The difference in incidence of such diseases as it grew through time was statistically significant for both genders; behind this growth was hypodynamia associated with extensive use of computers and mobile phones [10]. The data from this study coincide with the results we obtained from the Mokshino rural outpatient clinic in 2016.

In the Republic of Belarus, the prevalence of dorsopathy was $8,008.5 \pm 4,804.6$ cases per 100,000 people (depending on the region) in 2001 [11]. Even with the maximum registered in Belarus, which is $12,813.1$ cases per 100,000 people, is 1.7 times smaller than the incidence according to the Mokshino rural outpatient clinic records of 2011, which is $21,366.34$ cases per 100,000 people.

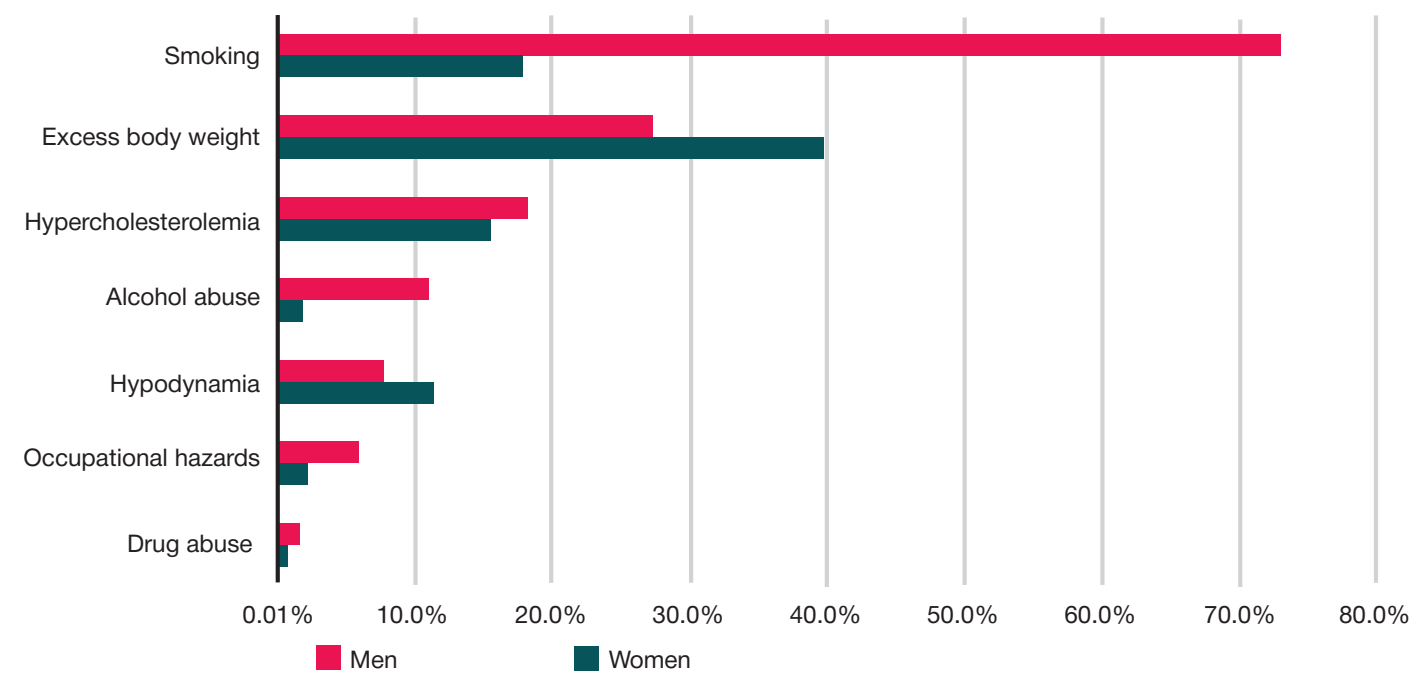

Fig. 3. Risk factors peculiar to 1203 rural residents, broken down gender-wise. 100\% equals 540 men 663 women: HD — hypodynamia, HCL — hypercholesterolemia, AA - alcohol abuse, EBW — excess body weight

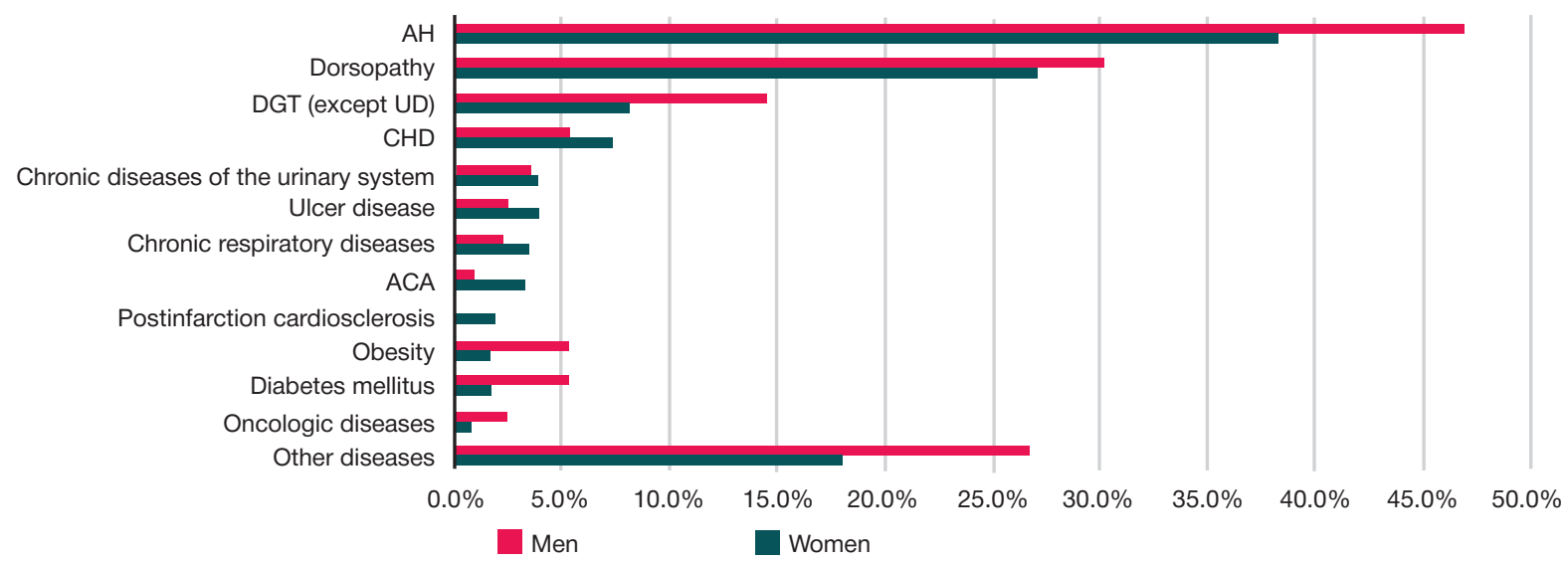

Fig. 4. Noncommunicable chronic diseases diagnosed in 1203 rural residents. 100\% equals 540 men 663 women: AH — arterial hypertension, DGT (except UD) diseases of the gastrointestinal tract, CHD - coronary heart disease, ACA - acute cerebrovascular accident, PCS - postinfarction cardiosclerosis, DM - diabetes mellitus, CDUS - chronic diseases of the urinary system, CRD — chronic respiratory diseases, UD - ulcer disease 


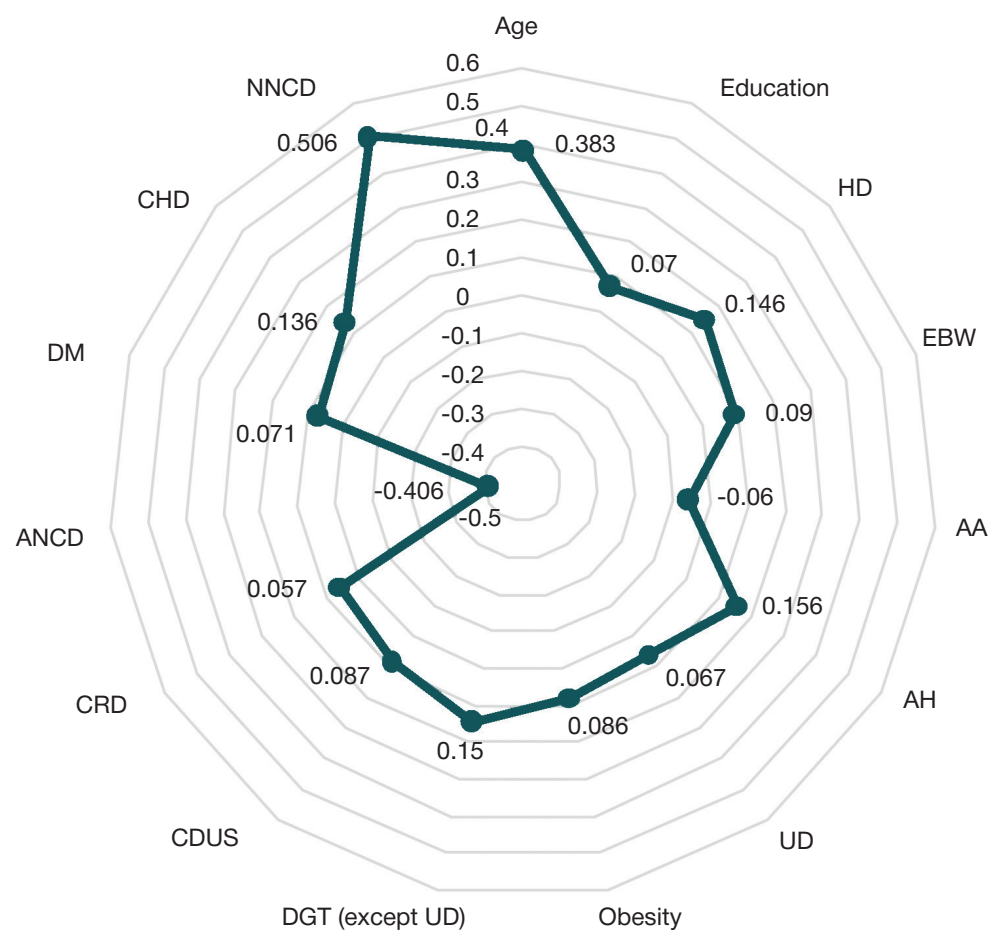

Fig. 5. SRCC values for dorsopathy and other factors peculiar to the population group of rural residents studied: AH — arterial hypertension, HD — hypodynamia, AA - alcohol abuse, DGT (except UD) — diseases of the gastrointestinal tract, CHD - coronary heart disease, EBW — excess body weight, NNCD - numerous noncommunicable chronic diseases, ANCD - absence of noncommunicable chronic diseases, DM - diabetes mellitus, CDUS - chronic diseases of the urinary system, CRD — chronic respiratory diseases, UD — ulcer disease

An interesting study was conducted by American researchers: they aimed to determine the trabecular bone structure tensor [12]. The study proves there is an association between DMSCTs and hypodynamia; in the population group we studied, the SRCC between the two was 0.146. Citing the Wolff's law, the researchers have experimentally proven the need for moderate loads on musculoskeletal system as a prerequisite for correct development of the bone structure.

A recommended component of the secondary routines to prevent dorsopathies are special "schools" for people suffering back pain [13]. There, the patients should learn of the importance of moderate locomotor activity, minimization of NCDs RF in their lives [14, 15], treatment of comorbidities and physiotherapy. Such schools are open in many countries, e.g. in Australia [16].

\section{CONCLUSIONS}

Dorsopathy is the $2^{\text {nd }}$ most common NCD found in the rural areas of the Tver region; the disease does not differentiate between types of occupations (heavy physical work and intellectual labor). The study shows that the number of patients diagnosed with dorsopathies grows proportionally to the number of those undergoing routine checkups, even with the number of visits to the outpatient clinic decreasing; thus, routine checkups is an effective tool for primary and secondary prevention of dorsopathy.

Dorsopathy is strongly correlated to comorbidities (NCDs), age; less so - to hypodynamia and even less so - to the type of the patient's occupation. Significantly more women had diabetes mellitus and obesity as comorbidities of dorsopathy than men. Coronary heart disease was detected in patients with dorsopathy in equal proportions gender-wise.

General practitioners treating dorsopathy patients in a rural outpatient clinic are recommended to set up schools for patients suffering back pain, where they should learn of the importance of moderate locomotor activity, minimization of NCDs RF in their lives, treatment of comorbidities and physiotherapy. Curricula given to general practitioners should include specifics of observation and treatment of senior patients living in rural areas, as well as the effect sedentary lifestyle resulting from computerization of society has on the development of dorsopathy.

\section{References}

1. Zdorov'e-2020: osnovy evropejskoj politiki i strategija dlja XX veka. Dostupno po ssylke: www.euro.who.int/_data/assets/ pdf_file/0017/215432/Health2020-Long-Rus.pdf.

2. Bojcov SA, Chuchalin AG, redaktory. Profilaktika hronicheskih neinfekcionnyh zabolevanij. Rekomendacii. M., 2013; 136.

3. WHO Scientific Group. Burden of musculoskeletal conditions at the start of the new millennium. Technical Report Series. Genove, Switzerland: World Health Organization; 2003: 1-218. Available from: http://www.who.int/iris/handle/10665/ 42721.

4. EUMUSC.NET. Musculoskeletal Health in Europe. Available from:

http://www.eumusc.net/myUploadData/files/30\%20August\%20 Final\%20draft\%20report.pdf [accessed 10 April 2016].

5. Mazurov VI, Lesnjak OM, redaktory. Osteoartrit. Revmatologija. Farmakoterapija bez oshibok: rukovodstvo dlja vrachej. M.: E-noto, 2017; c. 51-78.

6. Nikolaev JuA, Mitrofanov IM, Poljakov VJa i dr. Arterial'naja gipertenzija, svjazannaja s somaticheskoj patologiej, $\quad$ v sovremennoj praktike vnutrennih zabolevanij. Zdorov'e. 2014; 6 (1): 94-8.

7. Zdravoohranenie v Rossii. 2017: Statisticheskij sbornik Rosstat. M., 2017; 170. 
8. Shljafer SI. Ocenka sostojanija zdorov'ja sel'skogo naselenija starshe trudosposobnogo vozrasta $\vee$ Rossijskoj Federacii. Problemy social'noj gigieny, zdravoohranenija i istorii mediciny. 2014; (5): 13-19.

9. Chislennost' naselenija Rossijskoj Federacii po polu i vozrastu na 1 janvarja $2017 \mathrm{~g}$. Bjulleten'. Dostupno po ssylke: http://www. gks.ru/wps/wcm/connect/rosstat_main/rosstat/ru/statistics/ publications/catalog/doc_1140095700094.

10. Hagen K, Linde M, Heuch I, Stovner LJ, Zwart JA. Increasing prevalence of chronic musculoskeletal complaints: a large 11-year follow-up in the general population (HUNT 2 and 3). Pain Med. 2011; 12 (11): 1657-66. DOl:10.1111/j.15264637.2011.01240.x

11. Antipova SI, Valkevich VP, Antipov VW, Savina II. Bolezni kostnomyshechnoj sistemy i soedinitel'noj tkani v Belarusi — problema zdorov'ja i kachestva zhizni. Medicinskie novosti. 2013; (5): 50-55.

12. Kichenko AA, Tver'e VM, Njashin Jul, Zaborskih AA. Jeksperimental'noe opredelenie tenzora struktury trabekuljarnoj kostnoj tkani. Rossijskij zhurnal biomehaniki. 2011; 4 (54): 78-93.
13. Ostraja nespecificheskaja bol' $v$ spine. Rukovodstvo dlja vrachej obshhej praktiki (semejnyh vrachej). 2015, 15 s. Dostupno po ssylke: http://democenter.nitrosbase.com/clinrecalg5/Files/ recomend/\%D0\%92\%D0\%9E\%D0\%9F30.PDF

14. Karateev AE, Nasonov EL. Primenenie nesteroidnyh protivovospalitel'nyh preparatov pri revmaticheskih zabolevanijah. $\checkmark$ knige: Nasonov EL, redaktor. Rossijskie klinicheskie rekomendacii. Revmatologija. M.: GJeOTAR-Media, 2017; s. 339-59.

15. Komorbidnaja patologija $v$ klinicheskoj praktike. Klinicheskie rekomendacii. Obshherossijskaja obshhestvennaja organizacija Associacija vrachej obshhej praktiki (semejnyh vrachej). Sekcija «Sochetannye patologii». Kardiovaskuljarnaja terapija i profilaktika. 2017; 16 (6): 37-39. Dostupno po ssylke: http:// dx.doi.org/10.15829/1728-8800-2017-6-5-56.

16. Parreira P1, Heymans MW, van Tulder MW, Esmail R, Koes BW, Poquet $\mathrm{N}$, et al. Back Schools for chronic non-specific low back pain. Cochrane Database Syst Rev. 2017; Aug 3; 8. DOI: 10.1002/14651858.CD011674.pub2.

\section{Литература}

1. Здоровье-2020: основы европейской политики и стратегия для XXI века. Доступно по ссылке: www.euro.who.int/ data/ assets/pdf_file/0017/215432/Health2020-Long-Rus.pdf.

2. Бойцов С. А., Чучалин А. Г., редакторы. Просилактика хронических неинфекционных заболеваний. Рекомендации. M., 2013; 136

3. WHO Scientific Group. Burden of musculoskeletal conditions at the start of the new millennium. Technical Report Series. Genove, Switzerland: World Health Organization; 2003: 1-218. Available from: http://www.who.int/iris/handle/10665/42721.

4. EUMUSC.NET. Musculoskeletal Health in Europe. Available from: http://www.eumusc.net/myUploadData/files/30\%20August\%20 Final\%20draft\%20report.pdf [accessed 10 April 2016].

5. Мазуров В. И., Лесняк О. М., редакторы. Остеоартрит. Ревматология. Фармакотерапия без ошибок: руководство для врачей. М.: Е-ното, 2017; с. 51-78.

6. Николаев Ю. А., Митрофанов И. М., Поляков В. Я. и др. Артериальная гипертензия, связанная с соматической патологией, в современной практике внутренних заболеваний. Здоровье. 2014; 6 (1): 94-8.

7. Здравоохранение в России. 2017: Статистический сборник Росстат. М., 2017; 170.

8. Шляфер С. И. Оценка состояния здоровья сельского населения старше трудоспособного возраста в Российской Федерации. Проблемы социальной гигиены, здравоохранения и истории медицины. 2014; (5): 13-19.

9. Численность населения Российской Федерации по полу и возрасту на 1 января 2017 г. Бюллетень. Доступно по ссылке: http://www.gks.ru/wps/wcm/connect/rosstat_main/ rosstat/ru/statistics/publications/catalog/doc_1140095700094.

10. Hagen K, Linde M, Heuch I, Stovner LJ, Zwart JA. Increasing

prevalence of chronic musculoskeletal complaints: a large 11-year follow-up in the general population (HUNT 2 and 3). Pain Med. 2011; 12 (11): 1657-66. DOI:10.1111/j.1526-4637.2011.01240.x.

11. Антипова С. И., Валькевич В. П., Антипов В. В., Савина И. И. Болезни костно-мышечной системы и соединительной ткани в Беларуси - проблема здоровья и качества жизни. Медицинские новости. 2013; (5): 50-55.

12. Киченко А. А., Тверье В. М., Няшин Ю. И., Заборских А. А. Экспериментальное определение тензора структуры трабекулярной костной ткани. Российский журнал биомеханики. 2011; 4 (54): 78-93.

13. Острая неспецифическая боль в спине. Руководство для врачей общей практики (семейных врачей). 2015; 15 с. Доступно по ссылке: http://democenter.nitrosbase.com/ clinrecalg5/Files/recomend/\%D0\%92\%D0\%9E\%D0\%9F30.PDF.

14. Каратеев А. Е., Насонов Е. Л. Применение нестероидных противовоспалительных препаратов при ревматических заболеваниях. В книге: Насонов Е. Л., редактор. Российские клинические рекомендации. Ревматология. М.: ГЭОТАРМедиа, 2017; с. 339-59.

15. Коморбидная патология В клинической практике. Клинические рекомендации. Общероссийская общественная организация Ассоциация врачей общей практики (семейных врачей). Секция «Сочетанные патологии». Кардиоваскулярная терапия и профилактика. 2017; 16 (6): 37-39. Доступно по ссылке: http://dx.doi.org/10.15829/1728-8800-2017-6-5-56.

16. Parreira P1, Heymans MW, van Tulder MW, Esmail R, Koes BW, Poquet $\mathrm{N}$, et al. Back Schools for chronic non-specific low back pain. Cochrane Database Syst Rev. 2017; Aug 3; 8. DOI: 10.1002/14651858.CD011674.pub2. 